UDC 658.14/.17:005.52

DOI: https://doi.org/10.32782/2520-2200/2018-4-22

\author{
Ivanets I.V. \\ Candidate of Economic Sciences, \\ Associate Professor of the Department \\ of Corporate Finance and Controlling \\ Kyiv National Economic University named after Vadym Hetman
}

\title{
FINANCIAL ANALYSIS OF THE ACTIVITY OF THE ENTERPRISE
}

The implementation of an effective activity of an enterprise in a market economy is based on the creation of a modern system of information and analytical support for the management of financial and economic activities, the components of which are the analysis and control of financial and economic operations, processes and phenomena. In the conditions of growing competition on a global scale, the number of threats, and crisis in the economy, a positive financial result of the companies' activities comes to the fore. In the article theoretical and methodological bases of solvency analysis, liquidity, financial stability, cash and cash flows, efficiency of using the company's capital are disclosed and ways of its application are proposed in the process of strategic, tactical and operational management of the enterprise. On the example of the ABC company, the calculation of financial and economic activities was carried out with the distribution of financial analysis by the main groups of indicators, which in turn allows an objective assessment of the financial status, creditworthiness and investment attractiveness of the enterprise.

Key words. Financial analysis, capital structure, working capital, liquidity, profitability, solvency, financial stability, indicators.

Осуществление эфффективной деятельности предприятия в условиях рыночной экономики базируется на создании современной системы информационно-аналитического обеспечения управления финансово-хозяйственной деятельностью, составляющими которой является анализ и контроль финансово-хозяйственных операций, процессов и явлений. В условиях роста конкуренции в глобальных масштабах, количества угроз, кризисных явлений в экономике на первый план выходит получения положительного финансового результата их деятельности. В статье раскрыты теоретико-методические основы анализа платежеспособности, ликвидности, фринансовой устойчивости, денежных средств и их потоков, эффеективности использования капитала предприятия и предложены пути его применения в процессе стратегического, тактического и оперативного управления предприятием. На примере АBC осуществлен расчет фринансово-хозяйственной деятельности предприятия с распределением по основным группам показателей финансового анализа, что позволит объективно оценить уровень финансового состояния, кредитоспособности и инвестиционной привлекательности предприятия.

Ключевые слова: финансовый анализ, структура капитала, рабочий капитал, ликвидность, доходность, платежеспособность, финансовая стабильность, показатели.

Впровадження ефективної діяльності підприємства в умовах ринкової економіки базується на створенні сучасної системи інформаційно-аналітичного забезпечення управління фрінансово-господарською діяльністю, складовими якої є аналіз та контроль фрінансово-господарських операцій , процеси та явища. В умовах зростаючої конкуренції в глобальному масштабі в економіці прослідковується позитивний фрінансовий результат діяльності компаній. У статті розкриваються теоретичні та методологічні основи аналізу платоспроможності, ліквідності, фрінансової стабільності, грошових потоків та ефективності використання капіталу компанії, запропоновані шляхи його застосування в процесі стратегічного, тактичного та оперативного управління підприємством. На прикладі компанії АВС розрахунок фрінансово-господарської діяльності здійснювався за допомогою розподілу фінансового аналізу за основними групами показників, що, в свою чергу, дозволяє об'єктивно оцінити фрінансовий стан, кредитоспроможність та інвестиційну привабливість підприємства. Фінансовий аналіз - це процес вивчення даних про фрінансовий стан підприємства та результати його діяльності в минулому з метою оцінки майбутніх умов та результатів. Таким чином, основною метою фінансового аналізу є зменшення неминучої невизначеності, пов'язаної з прийняттям економічно орієнтованих рішень. Фінансовий аналіз дає можливість оцінити: структуру капіталу, аналіз робочого капіталу, аналіз ліквідності, рентабельність, платоспроможність, фінансову стабільність. Загальний фінансовий стан компанії АВС гарний. Компанія не має проблем з ліквідністю, структура капіталу є досить оптимальною. Компанія не має довгострокових боргів. Власні джерела фрінансування та короткострокові борги є достатніми для продовження 
діяльності. Компанія АВС збільшила свої активи протягом досліджуваного періоду. Це дає прибуток і генерує позитивні грошові потоки. Компанія має значну кількість вільного обігового капіталу і повинна використовувати цю можливість для інвестування в майбутні розробки. У мінливому зовнішньому економічному середовищі компанія повинна забезпечувати свою діяльність за непередбачуваних обставин. Під час підготовки стратегічних та операційних планів компанії необхідно розглянути як позитивний, так і негативний сценарій.

Ключові слова. Фінансовий аналіз, структура капіталу, робочий капітал, ліквідність, прибутковість, платоспроможність, фрінансова стабільність, показники.

Problem Introduction. In today's economic conditions, the activities of each enterprise, organization is the subject of attention of a wide range of market participants who are interested in the results of its functioning. On the basis of the accounting records available to them, these individuals attempt to assess the financial position of the enterprise. The main tool for this is the economic analysis, by which you can objectively assess the internal and external relations of the object, describe its solvency, efficiency and profitability of activities, prospects for development, and then based on its findings to make rational decisions.

Financial analysis is a process of the study of data on the financial position of the enterprise and the results of its activities in the past in order to assess future conditions and performance. Thus, the main purpose of financial analysis is to reduce the inevitable uncertainty associated with the adoption of future-oriented economic decisions.

Analysis of recent research and publications. There are differing approaches to the place of financial analysis in the economic science. Some conomists believe that it is an important part of financial management, others - that financial analysis is a separate science. Among the advocates of the first approach there are several economists, both Western - J.C. Van Horne (1996), E.F. Brigham and L.C. Gapenski (1997), E.A. Helfert (2003), P. Atrill (2006) etc., as well as Eastern - V. Kovalev (Ковалёв, 2002), I. Blank (Бланк,2004),G. Polyak (Поляк, 2009), E. orodina (Бородина, 2011), etc. [14]

The purpose of the article. Financial analysis is at the forefront of decision-making and action; it helps to substantiate the basis for it and guarantees the effectiveness, so the purpose of the article is to provide through the analysis the search for the options of use of the most economical resources, the possibilities for reduction of the prime cost of output as well as to increase the profit and profitability.

Presentation of the main research material. The objects of the enterprise financial analysis are the company business performance results that are studied in their dynamics and in correlation with several measures of business performance results. Financial analysis of the company is divided into main categories:
- Capital structure;

- Working capital analysis;

- Liquidity analysis;

- Profitability;

- Solvency;

- Financial stability analysis.

Capital structure ratios (sometimes called debt utilization or leverage ratios) compare the funds supplied by the owners (equity) with the funds provided by creditors (debt). The debt-to-assets ratio is calculated as total debt (i.e., the sum of current and long-term liabilities) divided by total assets; it measures the proportion of assets financed by borrowers. The debt-to-equity ratio is computed as total debt divided by stockholders' equity. The two ratios are computed as:

Debt-to-assets ratio = total debt / total assets;

Debt-to equity ratio = total debt / equity) [7, p. 60-61].

We have calculated debt-to-assets and debtto-equity ratios for $\mathrm{ABC}$ company (please, refer to Table 1).

Debt-to-equity ratio varies from year to year. Debt-to-assets ratio essentially correlate to debtto-equity ratio, as D/E ratio shows how much debt exceeds equity while D/A ratio shows what proportion of debt is in company capital.

The lowest value was in 2017 of D/E ratio was in 2017 ABC company increase its capital a lot due to retained earnings accumulation at the same tame liabilities decreased in 2017. In 2015 D/E ratio was the highest. This year debt comprise $70 \%$ of the equity. Foreign economists and manager consider such capital structure as the most optimal one. Since debt is cheaper than equity, and short-term debt is cheaper than long-term one. Company had a little long-term liabilities or didn't has it at all in 2013 and 2016, and this liabilities are presented not by bank loans, but by reimbursable financial assistance. Company's current liabilities are presented mainly by prepayment for services and internal settlements. So company's debt is cheap and doesn't risky way of financing.

Working capital analysis. Working capital is a measure of both a company's efficiency and its short-term financial health. Working capital is calculated as:

Net Working Capital $=$ Current Assets - Current Liabilities 
Capital structure analysis of ABC company in 2014-2017

\begin{tabular}{|l|c|c|c|c|}
\hline & $\mathbf{1 2 / 3 1 / 2 0 1 4}$ & $\mathbf{1 2 / 3 1 / 2 0 1 5}$ & $\mathbf{1 2 / 3 1 / 2 0 1 6}$ & $\mathbf{1 2 / 3 1 / 2 0 1 7}$ \\
\hline Equity & 31,092 & 31,462 & 95,926 & 167,155 \\
\hline Current liabilities & 37,969 & 73,564 & 123,658 & 108,487 \\
\hline Long-term liabilities & - & 681 & 570 & - \\
\hline Total Debt & 37,969 & 74,245 & 124,228 & 108,487 \\
\hline Assets & 69,061 & 105,707 & 220,154 & 275,642 \\
\hline D/E ratio & 1.22 & 2.36 & 1.30 & 0.65 \\
\hline D/A ratio & $55 \%$ & $70 \%$ & $56 \%$ & $39 \%$ \\
\hline
\end{tabular}

Table 2

ABC company working capital analysis in 2014-2017

\begin{tabular}{|l|c|c|c|c|}
\hline \multicolumn{1}{|c|}{ Indicator } & $\mathbf{1 2 / 3 1 / 2 0 1 4}$ & $\mathbf{1 2 / 3 1 / 2 0 1 5}$ & $\mathbf{1 2 / 3 1 / 2 0 1 6}$ & $\mathbf{1 2 / 3 1 / 2 0 1 7}$ \\
\hline Current assets & 61,955 & 99,530 & 212,344 & $\mathbf{2 6 6 , 0 0 4}$ \\
\hline Current liabilities & 37,969 & 73,564 & 123,658 & 108,487 \\
\hline Revenue & 174,754 & 183,143 & 291,739 & 317,802 \\
\hline Net working capital & 23,986 & 25,966 & 88,686 & 157,517 \\
\hline Net working capital ratio & 1.63 & 1.35 & 1.72 & 2.45 \\
\hline Average working capital & - & 24,976 & 57,326 & 123,102 \\
\hline Days working capital & - & 50 & 72 & 141 \\
\hline
\end{tabular}

The working capital ratio (Current Assets/Current Liabilities) indicates whether a company has enough short term assets to cover its short term debt. Anything below 1 indicates negative W/C (working capital). While anything over 2 means that the company is not investing excess assets. Most believe that a ratio between 1.2 and 2.0 is sufficient. Also known as "net working capital". [2].

Days working capital is an accounting and finance term used to describe how many days it takes for a company to convert its working capital into revenue. It can be used in ratio and fundamental analysis. When utilizing any ratio, it is important to consider how the company compares to similar companies in the same industry. Days working capital $=$ (Average working capital ${ }^{*}$ * 365) / Annual sales revenue

We have calculated net working capital, net working capital and days working capital for ABC company for the period 2014-2017 (Table 2). Net working capital increased a lot during 2014-2017 years generally due to significant increase in current assets specifically cash and cash equivalents. Cash and cash equivalents increased from 16 millions in 2014 to 192 millions in 2017.

Net working capital ratio in 2014-2016 was between 1.35 and 1.72, which means about sufficient amount of working capital and no liquidity risk. In 2017 ABC company net working capital ratio was 2.45. Economists consider such amount of current assets in comparison to current liabilities exceeding. Cash, which is component of current assets in 2017, should have been invested in activity development. Company lost investing opportunities by not used working capital excess.

Days working capital changed from 50 days to 141 days. It means that period of converting working capital into revenue increased, which affirm reduction of efficiency of working capital use.

Liquidity analysis. Three basic ratios are usually calculated in process of liquidity analysis. They are current ratio, Quick ratio and Cash ratio.

1. Current Ratio $=$ Current Assets $/$ Current Liabilities

Evaluates the ability of a company to pay shortterm obligations using current assets (cash, marketable securities, current receivables, inventory, and prepayments).

2. Acid Test Ratio = Quick Assets / Current Liabilities

Also known as "quick ratio", it measures the ability of a company to pay short-term obligations using the more liquid types of current assets or "quick assets" (cash, marketable securities, and current receivables).

3. Cash Ratio $=($ Cash + Marketable Securities $) /$ Current Liabilities

Measures the ability of a company to pay its current liabilities using cash and marketable securities. Marketable securities are short-term debt instruments that are as good as cash [4].

We have calculated liquidity ratios for $A B C$ company in the period 2014-2017 years and defined changes happened (please, refer to Table 3).

Current ratio of $A B C$ company varies from 1.35 to 2.45 during period $2014-2017$ years. Normal range for current ratio is from 1.5 to 2.5 depending 
Table 3

ABC company liquidity analysis in 2014-2017 years

\begin{tabular}{|l|c|c|c|c|}
\hline \multicolumn{1}{|c|}{ Indicator } & $\mathbf{1 2 / 3 1 / 2 0 1 4}$ & $\mathbf{1 2 / 3 1 / 2 0 1 5}$ & $\mathbf{1 2 / 3 1 / 2 0 1 6}$ & $\mathbf{1 2 / 3 1 / 2 0 1 7}$ \\
\hline Current assets & 61,955 & 99,530 & 212,344 & $\mathbf{2 6 6 , 0 0 4}$ \\
\hline Inventory & 25,390 & 19,468 & 20,570 & 27,734 \\
\hline Cash and cash equivalents & 16,192 & 54,117 & 162,106 & 191,826 \\
\hline Current liabilities & 37,969 & 73,564 & 123,658 & 108,487 \\
\hline Current ratio & 1.63 & 1.35 & 1.72 & 2.45 \\
\hline Quick ratio & 0.96 & 1.09 & 1.55 & 2.20 \\
\hline Cash ratio & 0.43 & 0.74 & 1.31 & 1.77 \\
\hline
\end{tabular}

on industry. High current ratio - more than 2.5 can mean about inefficient capital structure.

Quick ratio normal level around 1. A company with a quick ratio of less than 1 cannot currently fully pay back its current liabilities. Quick ratio was higher than 1 in all periods except 2013 year. That means there is no risk that company will be unable to meet its short-term liabilities as it has enough cash or assets that can be quickly converted into cash. Although receivables sometimes are not such liquid as there seemed. You can never be sure in the debtors solvency[1].

Cash ratio consider only the most liquid assets - cash and cash equivalents and current financial investments. Normal level more or equal 0.2. Cash ratio of $A B C$ company is high during all investigated period. Cash ratio higher than 1 means that $A B C$ company can pay all it current liabilities at any one time. At first glance it is positive scenario, but when large excess of cash appear, a good decision is to invest these cash in fixed assets, learning and development, new markets and new clients attraction etc.

Such large amount of cash at the year end can be explained by some seasonal fluctuation in activity and cash flows. Winter is a busy season for the companies which provided financial services, especially for audit department. That's way in the year end when customers pay for services already provided and make prepayments for future projects cash can rise significantly for some period of time [5].

\section{Profitability Ratios.}

1. Gross Profit Margin = Gross Profit $/$ Revenue

Evaluates how much gross profit is generated from sales. Gross profit is equal to sales minus cost of sales.

2. Operating margin = Operating income / Revenue

Operating margin is a measurement of what proportion of a company's revenue is left over after paying for variable costs of production such as wages, raw materials, etc. It can be calculated by dividing a company's operating income (also known as "operating profit") during a given period by its net sales during the same period.

3. Return on Sales $=$ Net Income $/$ Revenue
Also known as "net profit margin" or "net profit rate", it measures the percentage of income derived from dollar sales. Generally, the higher the ROS the better.

4. Return on Assets $=$ Net Income / Average Total Assets

In financial analysis, it is the measure of the return on investment. ROA is used in evaluating management's efficiency in using assets to generate income.

5. Return on Stockholders' Equity $=$ Net Income $\div$ $\div$ Average Stockholders' Equity[8]

We have calculated profitability ratios for $A B C$ company in order to analyze income formation and profitability dynamics (please, refer to Table 4).

$A B C$ company gross profit margin increased in every of investigated years. Gross profit margin in 2017 was $62.43 \%$. This means ABC earns 62.43 hryvnas on the 100 hryvnas of revenue in gross margin. Since cost of sales which comprised $64 \%$ of revenue in 2014 decreased to $37.5 \%$ in 2017. This is possible because of the fact that there is some fixed costs, which are included in costs of sales, and with growth in sales company uses economy of scope effect.

Operating profit margin in 2014-2015 was low. In 2016-2017 company with increase in revenues increased operating profit. The explanation of this situation can be found while looking at the amount of administrative expenses and other components of operating expenses. Company has fixed amount of administrative and managerial personnel, while number of client serving personnel can wary depending on number of projects, company is involved in. So company have some fixed salary expenses, also expenses for office maintenance (rent, utilities), expenses connected with computer software maintenance, access to paid informational resources. These expenses remains stable even in case of sales decrease. When demand for company services raised company incurs additional expenses (for example: salaries of new personnel).

Net profit margin is very similar to operating margin as company doesn't had some significant amounts of non-operating income or expenses during 2014-2017 years. 
Table 4

ABC company profitability ratios in 2014-2017

\begin{tabular}{|l|c|c|c|c|}
\hline \multicolumn{1}{|c|}{ Indicator } & $\mathbf{2 0 1 4}$ & $\mathbf{2 0 1 5}$ & $\mathbf{2 0 1 6}$ & $\mathbf{2 0 1 7}$ \\
\hline Revenue & 174,754 & 183,143 & 291,739 & 317,802 \\
\hline Gross profit & 76,641 & 83,344 & 163,435 & 198,416 \\
\hline Operating income & 11,333 & 1,657 & 71,675 & 71,890 \\
\hline Net income & 9,914 & 370 & 64,466 & 71,229 \\
\hline Average assets & - & 87,384 & 162,931 & 247,898 \\
\hline Average equity & - & 31,277 & 63,694 & 131,541 \\
\hline Gross profit margin, \% & $43.86 \%$ & $45.51 \%$ & $56.02 \%$ & $62.43 \%$ \\
\hline Operating margin, \% & $6.49 \%$ & $0.90 \%$ & $24.57 \%$ & $22.62 \%$ \\
\hline Net profit margin, \% & $5.67 \%$ & $0.20 \%$ & $22.10 \%$ & $22.41 \%$ \\
\hline ROA, \% & - & $0.42 \%$ & $39.57 \%$ & $28.73 \%$ \\
\hline ROE, \% & - & $1.18 \%$ & $67.20 \%$ & $42.61 \%$ \\
\hline
\end{tabular}

ABC company solvency analysis for the period 2013-2016

\begin{tabular}{|l|c|c|c|c|}
\hline \multicolumn{1}{|c|}{ Indicator } & $\mathbf{2 0 1 4}$ & $\mathbf{2 0 1 5}$ & $\mathbf{2 0 1 6}$ & $\mathbf{2 0 1 7}$ \\
\hline Net income & 9,914 & 370 & 64,466 & 71,229 \\
\hline Depreciation & 1,894 & 2,049 & 2,275 & 2,798 \\
\hline Debt & 37,969 & 74,245 & 124,228 & 108,487 \\
\hline Solvency ratio & $\mathbf{0 . 3 1}$ & $\mathbf{0 . 0 3}$ & $\mathbf{0 . 5 4}$ & $\mathbf{0 . 6 8}$ \\
\hline EBIT & 11,333 & 1,657 & 71,675 & 71,890 \\
\hline Interest expenses & 107 & 110 & 112 & 63 \\
\hline Times interest earned & $\mathbf{1 0 6}$ & $\mathbf{1 5}$ & $\mathbf{6 4 0}$ & $\mathbf{1 , 1 4 1}$ \\
\hline
\end{tabular}

Return on assets was very low in 2015 , due to low amount of net income in this year. In next years ROA was high enough, but in 2017 was significant increase of assets amount while net income increase wasn't such fast. So ROA became a little bit lower.

Return on Equity in 2016-2017 was high enough while looking at industry and economic situation in country. Company ROE $46.61 \%$ in 2016 means that each $\mathrm{UAH}$ of equity generates $0,46 \mathrm{UAH}$ of net income.

Solvencyanalysis. A key metric used to measure an enterprise's ability to meet its debt and other obligations. The solvency ratio indicates whether a company's cash flow is sufficient to meet its shortterm and long-term liabilities. The lower a company's solvency ratio, the greater the probability that it will default on its debt obligations.

The measure is usually calculated as follows:

Solvency ratio $=($ Netincome $($ or After-TaxProfit $)+$ + Depreciation) / Debt

The times interest earned ratio measures the ability of an organization to pay its debt obligations. The ratio is commonly used by lenders to ascertain whether a prospective borrower can afford to take on any additional debt. The ratio is calculated by comparing the earnings of a business that are available for use in paying down the interest expense on debt, divided by the amount of interest expense. The formula is:
Times interest earned $=$ Earnings before interest and taxes / Interest expense.

We have calculated ratios for $A B C$ company solvency analysis (please, refer to Table 5).

The solvency ratio is only one of the metrics used to determine whether a company can stay solvent. Other solvency ratios include debt to equity, total debt to total assets, and interest coverage ratios[9].

However, the solvency ratio is a comprehensive measure of solvency, as it measures cash flow rather than net income - by including depreciation to assess a company's capacity to stay afloat. It measures this cash flow capacity in relation to all liabilities, rather than only debt. Apart from debt and borrowings, other liabilities include short-term ones such as accounts payable and long-term ones such as capital lease and pension plan obligations.

Measuring cash flow rather than net income is a better determinant of solvency, especially for companies that incur large amounts of depreciation for their assets but have low levels of actual profitability. Similarly, assessing a company's ability to meet all its obligations - rather than debt alone - provides a more accurate picture of solvency. A company may have a low debt amount, but if its cash management practices are poor and accounts payable is surging as a result, its solvency position may not be as solid as would be indicated by measures that include only debt. 
Solvency of $A B C$ company have increased in two last years and now there is low risk that company will be unable to fulfill its obligations. But in 2015 year company experienced solvency difficulties as its cash flow was too low to cover current and long-term debt.

Generating cash flow to make principal and interest payments and avoiding bankruptcy depends on a company's ability to produce earnings. A company's capitalization refers to the amount of money it has raised by issuing stock or debt, and choices about capitalization impact the TIE ratio. Businesses consider the cost of capital for stock and debt, and they use that cost to make decisions about capitalization [3].

ABC company Times interest earned ratio shows that the company have enough earnings that are available for use to cover interest expenses on debt in 201402016 years.

Financial stability analysis. We have calculated financial stability type for the $A B C$ company for the period 2014-2017 years (see Table 6). We have studied ABC company ability to finance material working capital by its own sources. Material working capital covers inventories and prepaid expenses.

In 2014 company have solvency problems. Own sources of current assets financing was not enough to cover material working capital. At that year company didn't have long-term debt, which considered as equal to own sources of capital.

Ratio equals 0.9 in 2014 while sufficient value is 1 and more. Shortage can be cover by planned sources of financing-accounts payables. So despite the fact that in 2014 there was violation of solvency, company can find the way to solve this problem as it has enough planned sources of financing.

In 2015-2017 ABC company had high financial solvency. Amount of own sources of current assets financing (total equity minus fixed assets) was high sufficient to finance material working capital (inventory and prepaid expenses).

Conclusion. Overall financial condition of the ABC company is good. Company doesn't have liquidity problems, its capital structure quite optimal. Company doesn't has long term debt. Own sources of financing and short-term debt are sufficient for activity continuance. ABC company increased its assets during investigated period. It makes profits and generates positive cash flows. Company has significant amount of free working capital and should use this opportunity for investing in future developments. In changeable external economic environment company should secure its activity from unforeseen circumstances. While preparing strategic and operating plans company need to consider both positive and negative scenario, since nobody knows what can happens in future.

Financial stability analysis of ABC Company in the period 2014-2017

\begin{tabular}{|c|c|c|c|c|c|}
\hline № & Indicator & 2014 & 2015 & 2016 & 2017 \\
\hline 1 & $\begin{array}{l}\text { Material Working Capital (Stocks and } \\
\text { Expenses) }\end{array}$ & 26,575 & 20,662 & 22,667 & 30,518 \\
\hline 2 & Total equity & 31,092 & 31,462 & 95,926 & 167,155 \\
\hline 3 & Fixed assets & 7,106 & 6,177 & 7,810 & 9,638 \\
\hline 4 & $\begin{array}{l}\text { Own sources of current assets } \\
\text { financing }(2-3)\end{array}$ & 23,986 & 25,285 & 88,116 & 157,517 \\
\hline 5 & Equal to own sources of capital & - & 681 & 570 & - \\
\hline 6 & Own working capital $(2+5-3)$ & 23,986 & 25,966 & 88,686 & 157,517 \\
\hline 7 & Short term bank loans & - & - & - & - \\
\hline 8 & $\begin{array}{l}\text { Accounts payable for goods, works, } \\
\text { services }\end{array}$ & 1,364 & 931 & 394 & 2,030 \\
\hline 9 & $\begin{array}{l}\text { Accounts payable on received } \\
\text { advances }\end{array}$ & 24,720 & 48,278 & 61,756 & 65,839 \\
\hline 10 & $\begin{array}{l}\text { Planned sources of financing } \\
\text { of current assets }(6+7+8+9)\end{array}$ & 50,070 & 75,175 & 150,836 & 225,386 \\
\hline 11 & \multicolumn{5}{|c|}{ The level of security of the company by sources of financing: } \\
\hline 11.1. & Own sources of funding (4/1) & 0.9 & 1.22 & 3.89 & 5.16 \\
\hline 11.2. & Own working capital (6/1) & 0.9 & 1.26 & 3.91 & 5.16 \\
\hline 11.3. & $\begin{array}{l}\text { Planned sources of financing of } \\
\text { current assets (10/1) }\end{array}$ & 1.88 & 3.64 & 6.65 & 7.39 \\
\hline \multirow[b]{2}{*}{12} & \multirow[b]{2}{*}{ Financial stability type } & $(0 ; 0 ; 1)$ & $(1 ; 1 ; 1)$ & $(1 ; 1 ; 1)$ & $(1 ; 1 ; 1)$ \\
\hline & & $\begin{array}{l}\text { Violation of } \\
\text { solvency }\end{array}$ & $\begin{array}{c}\text { High financial } \\
\text { solvency }\end{array}$ & $\begin{array}{c}\text { High financial } \\
\text { solvency }\end{array}$ & $\begin{array}{l}\text { High financial } \\
\text { solvency }\end{array}$ \\
\hline
\end{tabular}




\section{References}

1. Berk J., DeMarzo P., Corporate Finance //Global Edition 4th ed. - Pearson, 2016 - 1169 p.

2. Beta by Industry, Risk Premiums, Cost of Capital by Industry [Electronic source]. - Link: http://pages.stern.nyu.edu/ adamodar/

3. N. Bohatska, O. Haluik. Financial condition of the firm and ways of its improvement in business processes / N. Bohatska, O. Haluik // Young scientist. - 2013. - № 2. - p. 12-16.

4. Fridson Martin, Alvarez Fernando. Financial Statement analysis. A Practitioner's Guide // New York: Published by John Wiley \& Sons, Inc. - 2002. - 396 p.

5. Fabozzi F.J., Drake P.P. Finance: Capital Markets, Financial Management, and Investment Management. - Wiley, 2009. - 811 p.

6. Hill R.A. Strategic Financial Management - BoBoCoAe, RAH \& Ventus Publishing ApS - $2008-$ 108 pages. 1. Methodical recommendations on revealing signs of insolvency of the company and signs of actions to hide bankruptcy, fictitious bankruptcy or bring to bankruptcy // Official site of the Ministry of Economic Development and Trade of Ukraine [Electronic source]. - Link: http://me.kmu.gov.ua/control/uk/publish/article?art_id=161079\&cat_id=38738

7. How to manage Cash Flow [Electronic source]. - Link: https://www.inc.com/encyclopedia/ cashflow.html

8. lankovets T., Ju. Chernjuk. Comparison of current diagnostics model of bankruptcy probability: foreign and domestic experience / T. lankovets, Ju. Chernjuk // Economic science. - 2016. - № 20. - p. 58-62.

9. Kornieva N., Shapovalova I. Ways to improve the financial condition of companies / N. Kornieva, I. Shapovalova // Economic sciences. - 2014. - № 5. - p. 55-60.

10. Sokil L. The need to manage the cash flows of the company [Electronic source]. - Link: http://www.rusnauka.com/9 NND 2013/Economics/10 131963. doc.htm

11. Ways of financial recovery and prevent bankruptcy [Electrōnic source]. - Link: http://docsdrive.com/pdfs/ medwelljournals/jeasci/2017/653-659.pdf

12. https://smida.gov.ua/

13. Zelgalve E., Zaharchenko A. Transformation of the role of financial analysis in enterprise management [Electronic source]. - Link: https://ejournals.vdu.lt/index.php/management-organizations/article/ viewFile/780/710

14. http://www.ey.com 